\title{
HUBUNGAN PENGETAHUAN DENGAN SIKAP AKSEPTOR KB SUNTIK TENTANG AKDR DI BPM NY. MIYARSIH, DESA SELODONO KECAMATAN RINGINREJO KABUPATEN KEDIRI
}

Susiani Endarwati, S.ST.M.Kes 1, Tri Wahyuni ${ }^{2}$

Akademi Kebidanan Dharma Husada Kediri Jawa Timur

\begin{abstract}
ABSTRAK
Angka Kematian Ibu (AKI) merupakan salah satu indikator untuk melihat derajat kesehatan perempuan. AKI dapat diturunkan dengan Keluarga Berencana. Rendahnya wawasan dan pengetahuan menyebabkan banyak orang bersikap negatifterhadap AKDR. Tujuan penelitian ini adalah mengetahui hubungan pengetahuan dengan sikap akseptor KB Suntik tentang AKDR di BPM Ny.Miyarsih,SST, Ds.Selodono, Kec.Ringinrejo, Kab.Kediri.

Desain penelitian menggunakan studi korelasi dengan pendekatan cross sectional. Populasi yang diteliti adalah semua akseptor KB suntik di BPM Ny.Miyarsih,SST, Ds.Selodono, Kec.Ringinrejo, Kab.Kediri sejumlah 106 pada bulan maret 2016. Teknik sampling menggunakan teknik Accidental Sampling dan didapatkan 60 responden.Variabel independent yang digunakan adalah pengetahuan akseptor KB Suntik dan variabel dependent adalah sikap tentang AKDR.Pengumpulan data menggunakan kuesioner, kemudian data diolah (editing, coding, scoring, tabulating) dan dianalisis dengan Chi Kuadrat.

Hasil penelitian dari 60 responden, 35 responden (58.33\%) berpengetahuan baik dengan sikap positif, 19 responden (31.67\%) berpengetahuan yang cukup dengan sikap positif, 2 responden $(3.33 \%)$ berpengetahuan baik dengan sikap negatif, 3 responden (5\%) berpengetahuan cukup dengan sikap negatif dan 1 responden $(1.67 \%)$ berpengetahuan kurang dengan sikap negatif. Dari hasil uji statistik Chi Kuadrat $(\alpha=5 \%)$ didapatkan $\chi^{2}$ hitung $10.19>\chi^{2}$ tabel 5.99 maka $\mathrm{H}_{1}$ diterima, artinya ada hubungan pengetahuan dengan sikap akseptor KB suntik tentang AKDR.

Berdasarkan penelitian tersebut diharapkan bidan meningkatkan pengetahuan responden melalui penyuluhan agar responden mengerti, memahami dan bersikap positif tentang AKDR.
\end{abstract}

Kata Kunci : Hubungan, Pengetahuan, Sikap, Akseptor KB Suntik, AKDR 


\section{PENDAHULUAN}

Alat Kontrasepsi Dalam Rahim merupakan suatu alat atau benda yang dimasukkan kedalam rahim yang sangat efektif, reversibel dan berjangka panjang, dapat dipakai oleh semua perempuan usia produktif (Handayani, Sri, 2010 : 139).

Profil kesehatan Indonesia tahun 2012 mencatat bahwa estimasi jumlah Wanita Usia Subur (WUS) tahun 2012 sejumlah 67.133 .347 orang atau sekitar $27,4 \%$ dari total jumlah penduduk Indonesia tahun 2012. Data Riskesdas (Riset Kesehatan Dasar) 2010 menyebutkan perkawinan pertama terbesar terjadi pada wanita berusia 15 19 tahun yaitu 41,9\%. Besarnya jumlah wanita usia subur dan usia muda yang telah melakukan perkawinan pertama di Indonesia membutuhkan perhatian khusus untuk dapat menjaga kesehatan reproduksi sehingga mendukung peningkatan kesehatan ibu dan penurunan AKI (Angka Kematian Ibu). (WHO, 2015).

Berdasarkan hasil wawancara secara acak kepada akseptor KB suntik pada saat peneliti mengikuti kegiatan praktek klinik bulan maret 2016 selama 2 minggu di BPM Ny. Miyarsih, SST dapat diketahui bahwa dari 20 akseptor KB suntik yang datang ke tempat pelayanan kesehatan, didapatkan hanya 8 Akseptor KB suntik yang mempunyai pengetahuan tentang AKDR, sedangkan 12 akseptor (60\%) dari akseptor KB suntik belum mempunyai pengetahuan tentang AKDR.

Dari 12 akseptor KB suntik yang yang belum perpengetahuan tentang AKDR didapatkan berbagai alasan diantaranya adalah biaya pemasangan AKDR yang menurutnya mahal atau takut menggunakan AKDR karena berbagai cerita dari orang lain yang tidak cocok menggunakan AKDR seperti terjadinya berbagai efek samping (nyeri, kram di perut, menstruasi lebih banyak dan berkepanjangan).

\section{METODE}

Pada penelitian ini desain penelitian yang digunakan adalah studi korelasi dengan pendekatan Cross Sectional.Populasi dalam penelitian ini adalah semua akseptor KB suntik di BPM Ny.Miyarsih, SST, Desa Selodono, Kecamatan Ringinrejo, Kabupaten Kediri. Teknik sampling menggunakan accidental samplingdi dapatkan sampel sejumlah 60 orang.

Variabel independen penelitian ini adalah pengetahuan akseptor KB suntik tentang AKDR di BPM Ny.Miyarsih, SST, Desa Selodono, Kecamatan Ringinrejo, Kabupaten Kediri.Variabel dependen dalam penelitian ini adalah sikap akseptor KB suntik tentang AKDR di BPM Ny. Miyarsih, SST, Desa Selodono, Kecamatan Ringinrejo, Kabupaten Kediri.

Instrumen yang digunakan dalam penelitian ini adalah kuesioner. Kuesioner terdiri dari 15 pernyataan tentang pengetahuan akseptor KB suntik tentang AKDR dan terdapat 15 pernyataan sikap akseptor $\mathrm{KB}$ suntik tentang AKDR.Hasil penelitian kuesioner yang telah dikumpukan lalu diolah dengan cara editing, coding, scoring, dan tabulating untuk pengujian hipotesa, kemudian dianalisa dengan Uji Chi kuadrat atau $\chi^{2}$. 
HASIL

a. Pengetahuan Akseptor KB Suntik AKDR

\begin{tabular}{|c|l|c|c|}
\hline No & \multicolumn{1}{|c|}{ Pengetahuan } & Frekuensi & \% \\
\hline 1. & Baik 76\%-100\% & 37 & 61.67 \\
\hline 2. & Cukup 56\%-75\% & 22 & 36.67 \\
\hline 3. & Kurang $<56 \%$ & 1 & 1.67 \\
\hline & Total & 60 & 100 \\
\hline
\end{tabular}

Berdasarkan Tabel IV.7 dapat diketahui dari 60 responden yang diteliti, didapatkan sebagian besar akseptor KB suntik berpengetahuan baik yaitu sebanyak 38 responden $(63.33 \%)$, sedangkan 1 responden $(1.67 \%)$ berpengetahuan kurang.

b. Sikap Akseptor KB Suntik tentang AKDR

\begin{tabular}{|c|l|c|c|}
\hline No. & Sikap & Frekuensi & \% \\
\hline 1. & Positif $(\mathrm{T} \geq 50)$ & 54 & 90 \\
\hline 2. & Negatif $(\mathrm{T}>50)$ & 6 & 10 \\
\hline \multicolumn{2}{|c|}{ Total } & 60 & 100 \\
\hline
\end{tabular}

Berdasarkan Tabel IV.8 dapat diketahui dari 60 responden yang diteliti, didapatkan sebagian besar akseptor KB suntik bersikap positif yaitu sebanyak 54 responden $(90 \%)$ dan 6 responden $(10 \%)$ bersikap negatif.

c. Hubungan Pengetahuan dengan Sikap Akseptor KB Suntik tentang AKDR

\begin{tabular}{|l|c|c|c|c|c|c|}
\hline \multirow{3}{*}{ Pengetahuan } & \multicolumn{4}{|c|}{ Sikap } & \multicolumn{2}{c|}{ Total } \\
\cline { 2 - 7 } & \multicolumn{2}{|c|}{ Positif } & \multicolumn{2}{c|}{ Negatif } & \multicolumn{2}{c|}{ J } \\
\cline { 2 - 7 } & Jml & \% & Jml & \% & Jml & \% \\
\hline Baik & 35 & 58.33 & 2 & 3.33 & 37 & 61.67 \\
\hline Cukup & 19 & 31.67 & 3 & 5 & 22 & 36.67 \\
\hline Kurang & 0 & 0 & 1 & 1.67 & 1 & 1.67 \\
\hline \multicolumn{1}{|c|}{ Total } & 54 & 90 & 6 & 10 & 60 & 100 \\
\hline
\end{tabular}

Dari hasil uji statistik Chi Kuadrat $\left(\chi^{2}\right)$ didapatkan $\chi^{2}$ hitung 10.19 dengan derajat kesalahan 5\% didapatkan $\chi^{2}$ tabel 5.99 maka $\chi^{2}$ hitung $>\chi^{2}$ tabel artinya ada hubungan yang signifikan antara pengetahuan dengan sikap akseptor KB suntik tentang AKDR di BPM Ny.Miyarsih, SST, Ds. Selodono, Kec. Ringinrejo, Kab.Kediri.

\section{DISKUSI}

1. Pengetahuan

Berdasarkan hasil penelitian pada tabel IV.7 menunjukkan dari 60 responden yang diteliti, didapatkan 37 responden $(61.67 \%)$ berpengetahuan baik, 22 responden $(36.67 \%)$ berpengetahuan cukup dan sisanya 1 responden $(1.67 \%)$ berpengetahuan kurang.

Pengetahuan responden yang baikdiharapkan pula responden dapat bersikap positif terhadap AKDR yang mungkin dalam jangka waktu dekat atau panjang responden dapat mempertimbangkan AKDR sebagai alat 
kontrasepsi untuk mencegah kehamilan selanjutnya.

Perlu peningkatan pengetahuan responden tentang jenis, kerugian dan efek samping ini. Biasanya seseorang yang mengerti dan memahami arti dari suatu objek, ia akan semakin penasaran untuk lebih mempelajari secara mendetail tentang objek tersebut, dalam hal ini objek itu adalah AKDR.

2. Sikap

Hasil dari Tabel IV.8 menunjukkan bahwa dari 60 responden yang diteliti, didapatkan sebagian besar akseptor KB suntik bersikap positif yaitu sebanyak 54 responden $(90 \%)$ dan 6 responden (10\%) bersikap negatif. Dalam tabulasi sikap pada lampiran 11, didapatkan prosentase sikap dalam komponen kognitif (perseptual) sebesar 33.93\%, komponen afektif (emosional) sebesar $32.57 \%$ dan komponen konatif (perilaku) sebesar $33.49 \%$.

Cara responden menyikapi AKDR ini juga dipengaruhi oleh berbagai komponen yaitu komponen kognitif (perseptual), komponen afektif (emosional), komponen konatif (perilaku).Tujuan utama dari semua komponen ini adalah responden bertindak atau berperilaku positif terhadap informasi yang diberikan, dalam bahasan ini adalah tentang AKDR. Beberapa cara pendekatan yang dapat dilakukan oleh tenaga kesehatan diantaranya dengan memperluas pengalaman pribadi, mempengaruhi orang lain yang dianggap penting di lingkungannya, pendekatan kebudayaan, melalui media massa, lembaga pendidikan dan lembaga agama serta memberi sugesti untuk mengubah pola pikir responden tentang AKDR.

3. Hubungan Pengetahuan dan Sikap Dari hasil uji statistik Chi Kuadrat $\left(\chi^{2}\right)$ didapatkan $\chi^{2}$ hitung 10.19 dan $\chi^{2}$ tabel 5.99 (dengan $\alpha 5 \%$ ) maka $\chi^{2}$ hitung $>\chi^{2}$ tabel artinya Ho ditolak dan $\mathrm{H}_{1}$ diterima, jadi ada hubungan yang signifikan antara pengetahuan dengan sikap akseptor KB suntik tentang AKDR di BPM Ny.Miyarsih, SST, Ds.Selodono, Kec. Ringinrejo, Kab.Kediri.

Berdasarkan tabel IV.9 menunjukkan dari 60 responden yang diteliti didapatkan 35 responden (58.33\%) mempunyai pengetahuan baik dengan sikap positif, 19 responden (31.67\%) mempunyai pengetahuan yang cukup dengan sikap positif, 2 responden $(3.33 \%)$ mempunyai pengetahuan baik dengan sikap negatif, 3 responden (5\%) mempunyai pengetahuan cukup dengan sikap negatif dan 1 responden responden (1.67\%) mempunyai pengetahuan kurang dengan sikap negatif. Dari hasil tabulasi silang tersebut dapat disimpulkan bahwa sebagian besar responden memiliki pengetahuan baik dengan sikap positif tentang AKDR.

Semakin banyak tahu, maka responden akan bersikap semakin baik terhadap AKDR. Penentuan sikap responden ini juga dipengaruhi oleh adanya dorongan diri sendiri, suami maupun keluarga.Begitu pula dengan berbagai komponen sikap yang turut mempengaruhi seseorang dalam mengambil tindakan / berperilaku. Berawal dari pengetahuan, pandangan dan keyakinan seseorang tentang informasi AKDR, selanjutnya seseorang akan mulai merumuskan perasaan senang atau tidak senang terhadap informasi AKDR tersebut. Setelah seseorang menentukan sikapnya, maka seseorang cenderung bertindak terhadap informasi tersebut, lalu ia akan menunjukkan besar kecilnya kecenderungan atau berperilaku terhadap informasi AKDR yang telah didapatkan.

Pengetahuan masyarakat dapat diperluas dengan adanya media cetak 
ataupun elektronik yang bisa lebih mudah menyampaikan berbagai informasi kepada masyarakat. Media ini

\section{SIMPULAN}

1. Pengetahuan 37 dari $60 \quad(61.67 \%)$ responden yang diteliti memiliki pengetahuan baik tentang AKDR.

2. Sikap 54 dari $60(90 \%)$ responden yang diteliti memiliki sikap positif tentang AKDR.

\section{DAFTAR PUSTAKA}

Affandi, dkk. 2011. Buku Panduan Praktis Pelayanan Kontrasepsi. Jakarta : PT.Bina Pustaka Sarwono Prawirohardjo.

Arikunto, Suharsimi. 2010. Prosedur Penelitian.Jakarta : Rineka Cipta.

Ariyani, Ayu Putri. 2014. Aplikasi Metodologi Penelitian Kebidanan dan Kesehatan Reproduksi.Yogyakarta : Nuha Medika.

Azwar, Saifudin. 2013. Sikap Manusia, Teori dan Pengukurannya. Yogyakarta : Pustaka Pelajar.

Everett, Suzanne. 2007. Buku Saku Kontrasepsi \& Kesehatan Seksual Reproduktif.Jakarta : EGC.

Handayani, Sri. 2010. Buku Ajar Pelayanan Keluarga Berencana. Yogyakarta : Pustaka Rihama.

Hidayat, Aziz Alimul. 2010. Riset Keperawatan dan Teknik Penulisan Ilmiah Edisi 2.Jakarta : Salemba Medika.

Notoatmodjo, Soekidjo. 2010 .Promosi Kesehatan dan Perilaku Kesehatan.Jakarta : Rineka Cipta.

. 2012 .Promosi Kesehatan dan Perilaku Kesehatan.Jakarta : Rineka Cipta.

Nursalam. 2013. Metodologi Penelitian Ilmu Keperawatan. Jakarta : Salemba Medika.

Mulyani, Nina Siti. 2013. Keluarga Berencana dan Alat Kontrasepsi. Yogyakarta: Nuha Medika. bisa menjadi media alternatif lain selain kegiatan penyuluhan yang dilakukan oleh tenaga kesehatan.

3. Ada hubungan antara pengetahuan dengan sikap akseptor KB suntik tentang Alat Kontrasepsi Dalam Rahim (AKDR) (berdasarkan hasil uji statistik Chi Kuadrat dengan $\alpha$ 5\%).

Prawirohardjo, Sarwono. 2008. Ilmu Kandungan.Jakarta : PT. Bina Pustaka

Setiyadi. 2007. Konsep dan Penulisan Riset Keperawatan. Yogyakarta : Graha Ilmu.

Wawan A. dan Dewi M. 2010.Teori dan Pengukuran Pengukuran Pengetahuan, Sikap dan Perilaku Manusia.Yogyakarta : Nuha Medika.

2008. Kamus Besar Bahasa Indonesia Pusat Bahasa Edisi Keempat.Jakarta : PT. Gramedia Pustaka Utama. 2011. KTI Kebidanan Keperawatan. Available from Https://www.wordpress.com.[Dia kses pada tanggal 21 April 2016].

86 | Jurnal Kebidanan Dharma Husada Kediri Vol.5, No.2 Oktober 2016 